\title{
Extension the Shelf-Life of Fresh Golden Rainbow Trout via Ultra-Fast Air or Cryogenic Carbon Dioxide Super Chilling
}

Vladimir Dimche Kitanovski ${ }^{1 *}$, Dessislava Borislavova Vlahova-Vangelova1 ${ }^{1}$, Stefan Georgiev Dragoev ${ }^{1}$, Hristo Nikolov Nikolov $^{2}$ and Dessislav Kostadinov Balev ${ }^{1}$

${ }^{1}$ Department of Meat and Fish Technology, University of Food Technology, Bulgaria

${ }^{2}$ Department of Preservation and Refrigeration Technology, University of Food Technology, Plovdiv, Bulgaria

\begin{abstract}
The objective of this study was to evaluate the possibilities of ultra-fast air or cryogenic super chilling by dry ice (carbon dioxide) for prolongation the shelf life of fresh golden albino of rainbow trout (Oncorhynchus mykiss), and to evaluate its effect on the fish quality comparing with flake ice chilling. The gutted fish $2 \mathrm{~h}$ post mortem was packed in transparent plastic polyvinyl dichloride bags with zipper. The first (control) sample was stored chilled at $0^{\circ} \mathrm{C}$ to $4^{\circ} \mathrm{C}$. The second group was cryogenic super chilled by dry ice $\left(\mathrm{CO}_{2}\right)$ at $-78^{\circ} \mathrm{C}$ with steam flow $0.5 \mathrm{~m} / \mathrm{s}$. The third group was ultra-fast super chilled with air at $-20^{\circ} \mathrm{C}$ with air flow $3 \mathrm{~m} / \mathrm{s}$ and stored at $2^{\circ} \mathrm{C}$ to $3^{\circ} \mathrm{C}$. All samples were examined on $0,7^{\text {th }}, 14^{\text {th }}$ and $21^{\text {st }}$ day of storage. On $21^{\text {st }} \mathrm{d}$ of storage comparison between supper chilled samples and flake ice chilled control indicated lower as follows: pH with $18.2 \%$, TVB-N with $24.1 \%$, FFA 9.5 times, POV about 2.5 times, TBARS and FAN approximately 2 times. The $10.40 \mathrm{mg}$ cadaverine/ $\mathrm{kg}$ in cryogenic dry $\mathrm{CO}_{2}$ super chilled golden rainbow trout was only determined. Sensory data show a continued acceptability of fish to 14 days for super chilled (to $21^{\text {st }} \mathrm{d}$ ) than in flake ice chilled (only to $7^{\text {th }} \mathrm{d}$ ). Microbiological shelf life was determined as $16-18$ days and $10-12$ days, respectively. The conclusion was made that the ultra-fast air flow super chilling retains better sensory qualities of golden rainbow trout while super chilling with dry carbon dioxide.
\end{abstract}

Keywords: Quality; Golden albino of rainbow trout; Oncorhynchus mykiss; Superchilled storage; Shelf life; FAN; TVB-N; FFA; POV; TBARS

Abbrevations: $0.1 \mathrm{M}$ : 0.1 Morality (The number of moles of solute dissolved in one litre of solution); $0.1 \mathrm{~N}$ : 0.1 Normality (The 'Normality' of a solution is the 'Morality' multiplied by the number of equivalents per mole for the molecule); ANOVA: Analysis of variance; AOAC: Association of Official Agricultural Chemists; $\mathrm{BaCl}_{2}$ : Barium dichloride; BHT: Butylated hydroxytoluene; C: Concentration; CA: California; $\mathrm{CO}_{2}$ : Carbon dioxide; FAMM: Facultative Anaerobic Mesophilic Microorganisms; FAN: Free $\alpha$-amino Nitrogen; Fe (II): The iron ion shares two of its electrons (Iron in ferrous stage); Fe (III): The iron ion shares three of its electrons (Iron in ferric stage); $\mathrm{FeSO}_{4}$ : Ferrous sulphate; FFA: Free Fatty Acids; $\mathrm{H}_{2} \mathrm{O}$ : Water; $\mathrm{H}_{2} \mathrm{SO}_{4}$ : Sulfuric acid; $\mathrm{K}_{2} \mathrm{IO}_{3}$ : Potassium periodate; $\mathrm{KOH}$ : Potassium hydroxide; MDA: Malondialdehyde; $\mathrm{N}_{2}$ : Nitrogen; $\mathrm{NaOH}$ : Sodium hydroxide; $\mathrm{pH}$ : Negative decimal logarithm of the concentration of free active hydrogen ion; PM: Psychrophilic Microorganisms; POV: Peroxide value; PVDC: Polyvinyl dichloride; SAS: Statistical Analysis System; SEM: Standard Error of the Mean; SCN: Thiocyanate; TBARS: 2-Tiobarbituric acid reactive substances; TCA: Trichloroacetic acid; TPC: Total Plate Count; TVB-N: Total volatile base nitrogen; USA: United States of America; UV-VIS: Ultraviolet-visible; V: Volume of a dilution factor of samples;

\section{W: Weight}

\section{Introduction}

The preservation is important for the fish reliability and safety. Fresh and high quality fish is in great demand worldwide [1]. Fish is a perishable food commodity. It needs better and more advanced preservation technology. That is way the temperature is a major factor determining the fish shelf life and quality, because its deterioration mainly occurs as a result of enzymatic, chemical and bacteriological activities leading to loss of freshness and subsequent spoilage [2]. On the other hand, the freshwater fish contains various nutritional ingredients, such as soluble proteins, active peptides, unsaturated fat and minerals that highly recommended by nutritionists [3]. Unfortunately, the freshwater fish is very perishable product, due to presence of endogenous enzymes promoting proteolysis of muscle proteins and connective tissue, as well as a lipid hydrolysis and oxidation, and microbial spoilage [4]. That is why, the development of effective preservation technologies for the shelf life extending, as saving the nutritional value and sensory properties of aquatic organisms become increasingly necessary. Nevertheless, how to maintain a stable and sufficiently low temperature during distribution and storage of fish is one of the most difficult challenges for fresh foods [5].

Golden rainbow trout is an albino form of rainbow trout. Albinism happens due to the missing oxidation activity of the enzyme tyrosinese [6]. Albinism is a recessive character and albino fish constitutes very little part of the population. The colour disadvantages of albinos greatly decrease chance to survive in the nature. However, in the farms, they have a much better chance to survive and some promising capabilities for demand on the market. Their number also can be increased through selective breeding [7]. The golden yellow pattern of the fish and its tender meat are attractive for the customers. On the other hand, the specific biology of golden trout contributes to a different proximate composition and sensory properties of the meat compared with normal trout. In various types of fish cold storage change their nutritional value and quality [8]. The iced pink salmon (Oncorhynchus gorbuscha) distinguished by seawater chilled with good quality during to ten days [9]. Other new chilling technique requires less time to fish

*Corresponding author: Vladimir Dimche Kitanovski, Department of Meat and Fish Technology, University of Food Technology, 26 Maritza blvd, 4002 Plovdiv, Bulgaria, Tel: 0038970462441; E-mail: k.vlade@hotmail.com

Received May 02, 2016; Accepted May 16, 2017; Published May 18, 2017

Citation: Kitanovski VD, Vlahova-Vangelova DB, Dragoev SG, Nikolov HN, Balev DK (2017) Extension the Shelf-Life of Fresh Golden Rainbow Trout via Ultra-Fast Air or Cryogenic Carbon Dioxide Super Chilling. J Aquac Res Development 8: 481. doi: 10.4172/2155-9546.1000481

Copyright: (c) 2017 Kitanovski VD, et al. This is an open-access article distributed under the terms of the Creative Commons Attribution License, which permits unrestricted use, distribution, and reproduction in any medium, provided the original author and source are credited. 
products. Liquid ice can reduce the time taken by fish until complete immobilisation but the temperature $\left(\approx-2.2^{\circ} \mathrm{C}\right)$ may significantly reduces the commercial value of the gilthead sea bream (Sparus aurata). The farmed fish species are highly perishable product. As a solution for protection the quality and freshness of rapidly declines post-mortem [10] fish offered the slurry ice use, and Lucas [11] applied the immersion chilling in binary brine solutions.

The best-known method for preservation the fish freshness is the application of the temperature of $2^{\circ} \mathrm{C}$ to $3^{\circ} \mathrm{C}$ below the water freezing point. This method is known as super chilling [12]. Super chilling is a method where the shelf life of rainbow trout can be prolonged by applying of superficial freezing based on an initial crystal formation [13]. Practically the super chilling has been defined as a process by which the temperature of a fish is lowered to $1^{\circ} \mathrm{C}$ to $2^{\circ} \mathrm{C}$ below the initial freezing point. Storing fish at super chilling temperature has three main advantages: maintaining its freshness, retaining high quality and suppressing growth of harmful microbes. The rate of bacterial spoilage at $-2^{\circ} \mathrm{C}$ is only $64 \%$ of that at $0^{\circ} \mathrm{C}(5)$. It can reduce the use of freezing/thawing and thereby to increase the yield, to reduce the energy, labour and transport costs [14]. The low temperatures allow reducing the need of external chilling. In this way, the quality of supper chilled fish is better than in frozen one since there is less freeze damage [15]. The definition of this method of preservation varies much, even the name has several versions mainly super chilling and partial freezing [16]. However, the principle is the same: cooling of the food with a few degrees under the initial crystallization point - between $-0.5^{\circ} \mathrm{C}$ and $-3.0^{\circ} \mathrm{C}$ [17]. This will guarantee a partial water freezing, initially only in the outer millimetres of the fish surface [18]. If the fish is super chilled the temperature equalizes and the water partially frozen out [19]. In the literature were described method for prolongation the shelf life of seer fish (Scomberomorus commersonii) packed in $20 \%$ dry ice (solid carbon dioxide) along with 50\% water ice and liquid nitrogen spraying [20].

No found information about application of super chilling by superquick air flow or dry carbon dioxide for extension the shelf life of fresh golden rainbow trout. That is why the aim of this work was to study the possibilities for use the super-quick air or cryogenic super chilling by dry ice (carbon dioxide), as new methods for prolongation the shelf life of fresh golden rainbow trout, and to assess their influence on the fish quality comparing with chilling using flake ice.

\section{Materials and Methods}

\section{Materials}

Sample preparation: The golden rainbow trout was taken from the fish farm 'Ribena' village of Zlatna Panega, Yablanitsa municipality, Lovech Province. Sixty fish were caught alive and electrically stunned with electrical power of $42 \mathrm{~W}$ and then put into styrofoam crates and buried with flake ice, which means that fish were killed with decreasing the temperature by encumbering in flake ice. After two hours, the fish were brought to the laboratory of the Department of Meat and Fish Technology of the University of Food Technologies-Plovdiv (Bulgaria), where they were divided into three groups of $20 \mathrm{fish}$. The fish was immediately gutted and eviscerated. The gutted golden rainbow trout was cleaned and thoroughly washed under running water to remove the complete stain of residues of blood clots. After washing, the drain fish was packaged in individual packages - weatherproof and airproofed transparent plastic polyvinyl dichloride (PVDC) bags with zipper ensuring airtight closure, with dimensions of $23 \times 31 \mathrm{~cm}$ and a thickness of $40 \mu$ (Opakovki.BG-Storage Ltd., Sofia, Bulgaria). Six fishes were taken for examination of the parameters $2 \mathrm{~h}$ post mortem that were actually our base data.
The first group of golden rainbow trout was used as a control samples. The fish from this group was chilled by flake ice and stored in refrigerator at air temperature $0^{\circ} \mathrm{C}$ to $4^{\circ} \mathrm{C}$. The second group of golden rainbow trout was cryogenic super chilled by dry ice $\left(\mathrm{CO}_{2}\right.$ carbon dioxide) steaming, located $15 \mathrm{~cm}$ away from the fish at $-78^{\circ} \mathrm{C}$ with steam flow $0.5 \mathrm{~m} / \mathrm{s}$. The third group of golden rainbow trout was ultra-fast super chilled with air at $-20^{\circ} \mathrm{C}$ with flow $3 \mathrm{~m} / \mathrm{s}$. The fish from second and third groups was tagged and stored in at $-2^{\circ} \mathrm{C}$ to $-3^{\circ} \mathrm{C}$. The fish samples were examined at the $0,7^{\text {th }}, 14^{\text {th }}$ and $21^{\text {st }}$ day of storage, six fishes from each group were taken for examination of the parameters per sampling date and the five repetition were made independently for each parameter. The average laboratory samples were prepared by homogenization of the fish muscles without skin. From this average samples, the quantity required was calibrated, as described in the appropriate method for research. Fish samples were taken randomly every 7 days for sensory, chemical and microbial analysis. The sensory characteristics: trout skin appearance, the state of the fish eyes, and the taste of grilled fish; chemical parameters such as: $\mathrm{pH}$ value, free fatty acids, peroxide value, TBARS, free amino nitrogen, total volatile base nitrogen, and biogenic amines; microbiological indicators such as: total plate count of facultative anaerobic mesophilic microorganisms in cfu/ $\mathrm{cm}^{-2}$ skin or $\mathrm{cfu} / \mathrm{g}^{-1}$ muscle tissue, and the psychrophilic microorganisms count in $\mathrm{cfu} / \mathrm{cm}^{-2}$ or $\mathrm{cfu} / \mathrm{g}^{-1}$ muscle tissue were examined.

\section{Methods}

Sensory evaluations: For sensory evaluation of the samples were used the scale from sensory assessment score sheets for fish and shellfish [21] which was undergo on some changes and modifications for the specific needs in our case. The sensory quality of golden rainbow trout was evaluated by a panel of seventh trained members from the laboratory staffs [22]. Panellists were scored for sensory characteristics using ten grade scale for samples of fresh fish referring to the appearance of skin and condition of the eyes, and nine-point hedonic scale grade scales for taste assessment of grilled fish (1, dislike extremely to $9 /$ or to $10 /$, like extremely). The median of panel members scores was calculated to evaluate the statistical analyses.

pH value: $\mathrm{pH}$ value of the samples was determined in a meat-water mixture [23]. $10 \mathrm{~g}$ of the homogenized sample was put into $100 \mathrm{ml}$ of distilled water and the mixture was filtered. The $\mathrm{pH}$ value of filtrate was measured using a digital pH meter Microsyst MS 2004 (Microsyst, Plovdiv), equipped with temperature and combined $\mathrm{pH}$ electrode type Sensorex Combination Recorder S450 CD (Sensorex pH Electrode Station, Garden Grove, CA, USA).

Free fatty acids: The acid value was measured using free fatty acids as an indication of hydrolytic rancidity of fish oil [24]. FFA in the oil extracted from a fish sample were determined by titration with a solution of potassium hydroxide $(\mathrm{KOH})$ with $0.1 \mathrm{~N}$ concentration and with phenolphthalein as a colour indicator. The acid value (or free fatty acid content) was determined by AOAC method 940.28 [25]. The oil sample $(0.2 \mathrm{~g})$ was dissolved in $10 \mathrm{~cm}^{3}$ ethanol and titrated with $0.1 \mathrm{M} \mathrm{NaOH}$ solution using phenolphthalein indicator until pink colour disappeared. The acid value and the percentage fatty acid were calculated from the expression bellow:

$$
\text { Acid Value }=\frac{56 \text { molarities of } \mathrm{NaOH} \text { xtiter value }}{\text { Weight of fishoil }}
$$

Free fatty acid $=0.503 \times$ Acid Acid Value, $\%$ Oleic acid

Peroxide value: POV was determined spectrophotometrically 
based on the oxidation of $\mathrm{Fe}$ (II) to $\mathrm{Fe}$ (III) in the presence of hydroperoxides and the formation of a coloured complex between obtained Fe (III) and SCN as described by Hornero-Méndez [26]. The sample $0.05 \mathrm{~g}$ was placed in $10 \mathrm{~mL}$ screw-capped test tube and dissolved in $1 \mathrm{~cm}^{3}$ chloroform/acetic acid (2:3), with addition of 100 $\mathrm{mm}^{3} \mathrm{Fe}$ (II) solution, mixed for $15 \mathrm{~s}$ on Vortex mixer (Heidolph, Schwabach, Germany), and left in the dark for $10 \mathrm{~min}$. Deionised water ( $2 \mathrm{~mL}$ ) wad added, and $4 \mathrm{~cm}^{3}$ of diethyl ether (containing ca $7 \mathrm{ngBHT}$ ) was used for fish oil extraction. Organic phase was discarded, and remaining either in the aqueous phase was removed under $\mathrm{N}_{2}$ current for a few seconds. To determine Fe (III), $1 \mathrm{~mL}$ of aqueous phase was transferred to a disposable plastic microfuge tube and mixed with 100 $\mathrm{mL}$ of saturated ammonium thiocyanate solution. After $10 \mathrm{~min}$, the absorbance at $470 \mathrm{~nm}$ was measured against the water blank (correction of the spectrum baseline at $670 \mathrm{~nm}$ was performed). A reaction blank containing all the reagents, except the sample, was also performed, and the resulting absorbance value was subtracted from that of the sample. $\mathrm{Fe}$ (II) stock solution was prepared by the gently mixing of solution of 0.4 of $\mathrm{BaCl}_{2} .2 \mathrm{H}_{2} \mathrm{O}$ in $50 \mathrm{~cm}^{3}$ deionised water with a solution of $0.5 \mathrm{~g}$ $\mathrm{FeSO}_{4} \cdot 7 \mathrm{H}_{2} \mathrm{O}$ in $50 \mathrm{~cm}^{3}$ deionised water. Concentrated hydrochloride acid $\left(2 \mathrm{~cm}^{3}\right)$ was added to the resolution solution, which was filtered and stored under cover. It is strongly recommended to prepare this solution as fresh as possible and check it stage before use by addition of a few drops of thiocyanate solution. Solution should be discarded if a pale pink colour appears. The absorbance was measured by twin ray spectrophotometer UV-VIS Camspec, model M550 (Camspec Ltd, Sawston, Cambridge, United Kingdom).

TBARS: TBARS was determined using the method of Botsoglou [27], following recommendations of Jebelli [28]. A 2 g sample was transferred into a $25 \mathrm{~mL}$ centrifugated tube, and volumes of $5 \%$ aqueous TCA $\left(8 \mathrm{~cm}^{3}\right)$, and $0.8 \mathrm{~mL}$ BHT in hexane $\left(5 \mathrm{~cm}^{3}\right)$ were successively added. The content of the tube was Ulta-Turraxed for $30 \mathrm{~s}$ at high speed and centrofugated for $3 \mathrm{~min}$ at $3000 \mathrm{~g}$, and the top hexane layer was discarded. The bottom aqueous layer was made to a $10 \mathrm{~mL}$ volume with a $5 \%$ TCA, and $2.5 \mathrm{~cm}^{3}$ aliquot was pipetted into a screw-capted tube to which a volume $\left(1.5 \mathrm{~cm}^{3}\right)$ of $0.8 \%$ aqueous TCA was added. Following incubation for $30 \mathrm{~min}$ at $70^{\circ} \mathrm{C}$, the tube was cooled under tap water, and reaction mixture was submitted to third-derivative spectrophotometry against blank reaction mixture. Aliquots of standard solutions were pipetted into screw-capped tubes and diluted to $2.5 \mathrm{~cm}^{3}$ volume with $5 \%$ TCA. A $1.5 \mathrm{~cm}^{3} 0.8 \%$ TCA was added in each tube and the reaction was carried out as prescribed. Calibration curves were constructing by plotting values of peak height at $521.5 \mathrm{~nm}$ were measured using twin ray spectrophotometer UV-VIS Camspec, model M550 (Camspec Ltd, Sawston, Cambridge, United Kingdom), as they are printed on the instrumental chart in arbitrary units, versus known concentration of MDA in the final reaction mixtures. MDA in samples was calculated using formula:

$$
M D A=\frac{16 \cdot C \cdot V}{W} \mu g / \mathrm{kg}
$$

C is the MDA concentration $\left(\mathrm{ng} / \mathrm{cm}^{3}\right)$ in the sample extracts according to the calibration curve,

\section{$\mathrm{V}$ is a dilution factor of sample extract $\left(\mathrm{cm}^{3}\right)$ if any, and}

$\mathrm{W}$ is the weight $(\mathrm{kg})$ of the sample.

Free $\boldsymbol{\alpha}$-amino nitrogen: Firstly, an extraction of soluble proteins was made with help of buffer $\mathrm{pH} 7.3$ homogenized with $2.5 \mathrm{~g}$ of meat and left for one night in refrigerator further developed by Abernathy [29]. The extract was diluted 20 times. $2 \mathrm{~cm}^{3}$ of diluted extract was transferred to a test tube, then was added $1 \mathrm{~cm}^{3}$ ninhydrin reagent. The samples were heated for exactly $16 \mathrm{~min}$ in constantly boiling water bath, and cooled for $20 \mathrm{~min}$ in water bath at $20^{\circ} \mathrm{C}$. Then $5 \mathrm{~cm}^{3}$ of diluted solution of $\mathrm{K}_{2} \mathrm{IO}_{3}$ was added. The absorbance on $570 \mathrm{~nm}$ was measured after $20 \mathrm{~min}$ with twin ray spectrophotometer UV-VIS Camspec, model M550 (Camspec Ltd, Sawston, Cambridge).

Total volatile base nitrogen: The total volatile basic nitrogen was determined according to the method described by Goulas and Kontominas [30]. The $5 \mathrm{~g}$ to $10 \mathrm{~g}$ of laboratory samples was measured. They were put in distillation flask with $200 \mathrm{~cm}^{3}$ of distillate water, to which were added litmus paper, $10 \mathrm{~cm}^{3}$ of liquid paraffin, $2 \mathrm{~g}$ of magnesium oxide mixed with $25 \mathrm{~cm}^{3}$ to $30 \mathrm{~cm}^{3}$ of distillate water. The reaction needed an alkaline reaction (litmus paper supposed to be blue). The distillation equipment which was used containing: steamer, distillation flask, lie big condenser, and receiving flask. The $20 \mathrm{~cm}^{3}$ to 30 $\mathrm{cm}^{3}$ of $\mathrm{H}_{2} \mathrm{SO}_{4}$ were put, and 3-5 drops of methyl rot as an indicator was added. After that the samples were titrated in the receiving flask with $0.1 \mathrm{~N} \mathrm{NaOH}$ until changing the colour from red to yellow.

Preparation of samples for microbiological analysis: A serial dilution with constant dilution factor was made. A tenfold dilution for each step which is called a logarithmic dilution or log-dilution was made. Once diluted, $1 \mathrm{~cm}^{3}$ of the diluted sample from various dilutions was added to sterile Petri plates (in triplicate for each dilution) to which molten and cooled $\left(45^{\circ} \mathrm{C}\right.$ to $\left.50^{\circ} \mathrm{C}\right)$ suitable agar medium was added [31].

Total plate count of facultative anaerobic mesophilic microorganisms: Total plate count of facultative anaerobic mesophilic microorganisms on the skin surface and inside in muscle tissue was done with seeding of the dilution sample from all dilutions to sterile labelled Petri plates. The molten and cooled $\left(45^{\circ} \mathrm{C}\right.$ to $\left.50^{\circ} \mathrm{C}\right)$ suitable agar medium was added and the plates were incubated for $72 \mathrm{~h}$ at $30^{\circ} \mathrm{C}$ following the ISO 4833:2003 [32] method.

Total plate count of psychrophilic microorganisms: Total plate count of psychrophilic microorganisms on the skin surface and in muscle tissue was made following the ISO 17410:2002 [33] method. Samples are diluted, and a subsample is placed in a sterile petri dish. Standard Methods agar is poured over the sample and swirled to mix. Agar is allowed to harden. Plates are inverted and incubated at $7^{\circ} \mathrm{C}$ $\pm 1^{\circ} \mathrm{C}$ for approximately 10 days. The Bacteria is identified and the colonies are counted.

Statistical analysis: Statistical analysis of the average values of fivetime reps was made. The descriptive statistics are described by mean \pm SEM. For quantitative data one way ANOVA and Turkey post hoc tests were used. A p-value less than 0.05 ( $p \leq 0.05$ ) was considered statistically significant. All statistical procedures were performed using the SAS software version 6.12 .

\section{Results and Discussion}

\section{Sensory evaluations}

A significant reduction of sensory scores after 21 days storage at all three samples were determined. A more pronounced decrease in sensory evaluations was found in control samples (chilled golden rainbow trout). The sensory score of control samples for state of the eyes decreases with $52.5 \%$ during 21 days storage, those for skin appearance decreases with $42.0 \%$, and for taste of grilled fish decreases with $52.2 \%$ were determined. The reductions of sensory scores of those parameters at supper chilled samples were between $22.5 \%$ to $32.5 \%$. The comparisons of data obtained between both supper chilled samples 
shows that after 7 days on, ultra-fast supper chilled samples were rated with significantly higher scores compared to the cryogenic supper chilled golden rainbow trout (Figure 1).

Moreover after 21 days storage, the ultra-fast supper chilling with cool air to a greater extent preserved the state of the eyes and skin appearance of golden rainbow trout. It was preserved better taste of the fish compared to samples cryogenic supper chilled with dry ice. The development of fish spoilage was obviously established as a feeling of rotting smell, greasy and softer flesh at the chilled golden rainbow trout after 14 days of storage of the control samples. The resulting sensory evaluations were in good agreement with the microbiological data. It has been found that cryogenic supper chilling of the golden rainbow trout with dry ice $\left(\mathrm{CO}_{2}\right)$ is probably too strong and lead to signs of a cold-burning on the surface of this delicate fish, such as is a golden albino of the rainbow trout (Figure 2).

Respectively, according to the sensory acceptability we can determine the chilled golden rainbow trout should not be stored for more than 14 days until, the cryogenic supper chilled by dry ice to 19 days, and ultra-fast supper chilled fish with cold air-up to 21 days. In this sense, judging by sensory changes, we can conclude that supper chilling of golden rainbow trout is the good method to extend the its shelf-life with 5 to 7 days compared with chilling (Figure 3).

Contrary to us [34] reported that sensory score is the limit for acceptability of rainbow trout fillets to only 5 days at $3^{\circ} \mathrm{C}$ and 11 days at $-3^{\circ} \mathrm{C}$, but similarly to as connected the sensory scores with TAC, TVB-N, and $\mathrm{K}$ value. Contrary to us [35] were determined that super chilling $\left(-2^{\circ} \mathrm{C}\right)$ of Arctic charr (Salvelinus alpinus) fillets packed

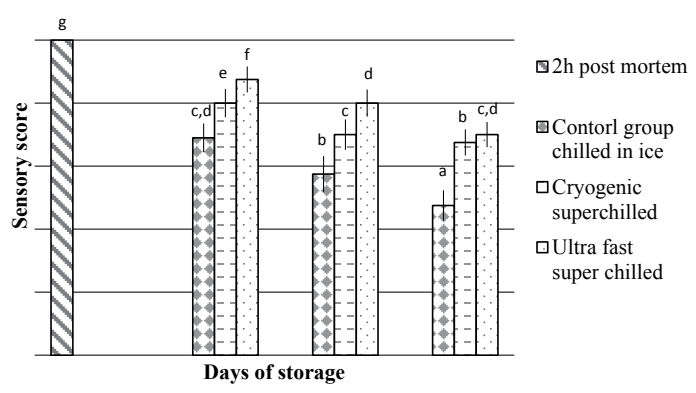

Figure 1: Eyes state sensory evaluation of golden rainbow trout (Oncorhynchus mykiss) stored and chilled in different ways Data were expressed as Mean $\pm S D$ $(n=7)$. a, b, c, d, e, f, g, - different letters indicated that values of the means in the rows are significantly different $\left({ }^{*} p<0.05\right)$.

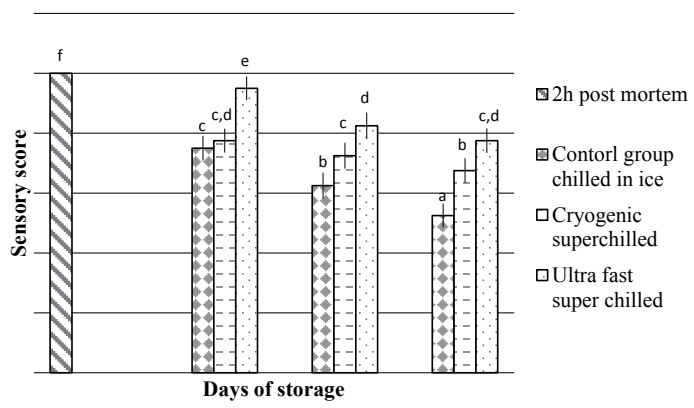

Figure 2: Skin appearance sensory evaluation of golden rainbow trout (Oncorhynchus mykiss) stored and chilled in different ways Data were expressed as Mean $\pm S D(n=7)$. ${ }^{a, b, c, d, e, f}$ - different letters indicated that values of the means in the rows are significantly different $\left({ }^{*} p<0.05\right)$.

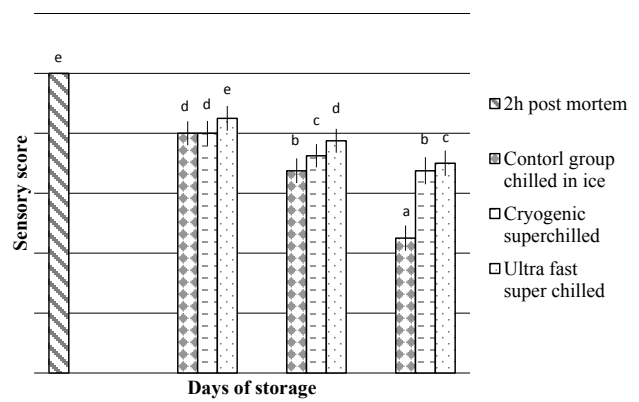

Figure 3: Cooked fish sensory evaluation of golden rainbow trout (Oncorhynchus mykiss) stored and chilled in different ways Data were expressed as Mean $\pm S D$ $(n=7)$. ${ }^{a}, b, c, d, e-$ different letters indicated that values of the means in the rows are significantly different $\left({ }^{*} p<0.05\right)$.

with dry ice resulted in 6 days extension of shelf life compared to chilling $\left(3^{\circ} \mathrm{C}\right)$.

The opposite of those researchers [36] defend close to our hypothesis, namely that supper chilled storage at $-2.2^{\circ} \mathrm{C}$ of fillet portions of farmed Atlantic cod (Gadus morhua) showed increased shelf life with respect to reduced growth of sulphide producing bacteria compared to ice chilled.

\section{pH value}

The mean $\mathrm{pH}$ values of the samples are presented in Table 1 . The $\mathrm{pH}$ of the fresh fish was 6.76. This indicates that during fish supply, preliminary processing for 'super chilling' and packaging the trout undergone post-mortem period of rigor mortis and it is in a phase of initial autolysis ("ripening"), caused by intensive hydrolysis of myofibrillar and collagenous proteins by proteases. During 21 days of refrigeration storage, $\mathrm{pH}$ of fish muscles increased marginally and reached to 7.99 and 6.99 to 7.01 at chilled and supper chilled golden rainbow trout, respectively. In the same time the control samples were rejected based on sensory evaluations, but two experimental groups supper chilled golden rainbow trout were accepted. Increase in $\mathrm{pH}$ during storage may be due to the production of amines and other volatile bases by the autolysis and microbial action on protein and other compounds confirm by our results for FFA, FAAN, TVB-N Table 1, TPC-FAMM and TPC-PM. The post mortem $\mathrm{pH}$ limit of acceptability is usually 6.8 7.0. In this study, chilled fish crossed this limit at after $7^{\text {th }}$ day of storage period. The $\mathrm{pH}$ of chilled fish increases with $18.2 \%$ on $21^{\text {st }} \mathrm{d}$ of storage. However, no significant difference in $\mathrm{pH}\left({ }^{*} \mathrm{p}>0.05\right)$ was observed between two experimental samples supper chilled golden rainbow trout. After 21-day storage, the $\mathrm{pH}$ of fish meat increases with $3.4 \%$ to $3.7 \%$. Our results are similar of the finding of $\mathrm{Mi}$ [37] which reported for controlled both TVB-N and TMA-N contents in super chilled grass carp under the acceptable values within 21 days of storage. Those authors $\mathrm{Mi}$ [37] suggested the super chilling of grass carp attenuated the denaturation of myofibrillar protein and the damage of muscle structure associated with freezing, where extractability of salt soluble protein and $\mathrm{Ca}^{2+}$-ATPase activity were reduced. A shelf life of 21 days for super chilled could be estimated by the overall quality evaluation.

Similar results for $\mathrm{pH}$ trends were also reported by were storied the Mystus seenghala at $4^{\circ} \mathrm{C} \pm 1{ }^{\circ} \mathrm{C}$ (chilled) and at $-12^{\circ} \mathrm{C} \pm 2^{\circ} \mathrm{C}$ (frozen) for 21 days, and by Liu et al. [17,38,39] were storied grass carp (Ctenopharyngodon idella) fillets at -3 and $0^{\circ} \mathrm{C}$. The $\mathrm{pH}$ increasing can by explain by partial denaturation of myosin $\mathrm{Li}$ et al. $[17,38,39]$ that is in direct linked with cathepsin activities and protein extractability 
Citation: Kitanovski VD, Vlahova-Vangelova DB, Dragoev SG, Nikolov HN, Balev DK (2017) Extension the Shelf-Life of Fresh Golden Rainbow Trout via Ultra-Fast Air or Cryogenic Carbon Dioxide Super Chilling. J Aquac Res Development 8: 481. doi: 10.4172/2155-9546.1000481

Page 5 of 9

\begin{tabular}{|c|c|c|c|c|c|c|c|c|c|c|}
\hline \multirow[t]{3}{*}{$\begin{array}{l}\text { Examined } \\
\text { parameter }\end{array}$} & & \multicolumn{3}{|c|}{$\begin{array}{c}\text { Control sample - Golden rainbow trout } \\
\text { (Oncorhynchus mykiss) chilled by flake ice } \\
\text { and stored at } 0^{\circ} \mathrm{C} \text { to } 4^{\circ} \mathrm{C}\end{array}$} & \multicolumn{3}{|c|}{$\begin{array}{c}\text { Cryogenic super chilled golden rainbow } \\
\text { trout (Oncorhynchus mykiss) by dry } \\
\text { carbon dioxide at }-78^{\circ} \mathrm{C} \text { with flow } 0.5 \mathrm{~m} / \mathrm{s} \text {, } \\
\text { and stored at }-2 \text { to }-3^{\circ} \mathrm{C}\end{array}$} & \multicolumn{3}{|c|}{$\begin{array}{c}\text { Ultra-fast super chilled golden rainbow } \\
\text { trout (Oncorhynchus mykiss) by cold air } \\
\text { at }-20^{\circ} \mathrm{C} \text { with flow } 3.0 \mathrm{~m} / \mathrm{s} \text {, and stored at } \\
-2^{\circ} \mathrm{C} \text { to }-3^{\circ} \mathrm{C}\end{array}$} \\
\hline & \multicolumn{10}{|c|}{ Day of storage } \\
\hline & Od & $7 d$ & 14d & 21d & $7 d$ & 14d & 21d & $7 d$ & 14d & 21d \\
\hline $\mathrm{pH}$ value & $6.76^{a} \pm 0.03$ & $6.94^{\mathrm{c}} \pm 0.01$ & $7.17^{\mathrm{e}} \pm 0.04$ & $7.99^{f} \pm 0.03$ & $6.85^{\mathrm{b}} \pm 0.02$ & $6.92^{b, c} \pm 0.03$ & $6.99^{d} \pm 0.03$ & $6.83^{b} \pm 0.02$ & $6.91^{\mathrm{b}, \mathrm{c}} \pm 0.02$ & $7.01^{d} \pm 0.04$ \\
\hline $\begin{array}{l}\text { Free fatty acids, } \\
\% \text { Oleic acid }\end{array}$ & $0.02^{\mathrm{a}} \pm 0.01$ & $0.06^{c} \pm 0.01$ & $0.10^{d} \pm 0.02$ & $0.19^{e} \pm 0.08$ & $0.04^{\mathrm{a}, \mathrm{b}} \pm 0.01$ & $0.05^{a, b} \pm 0.02$ & $0.05^{b, c} \pm 0.01$ & $0.04^{\mathrm{a}, \mathrm{b}} \pm 0.01$ & $0.05^{\mathrm{a}, \mathrm{b}} \pm 0.02$ & $0.05^{b, c} \pm 0.01$ \\
\hline $\begin{array}{c}\text { Peroxide value, } \\
{\text { Meq } \mathrm{O}_{2} / \mathrm{kg}}\end{array}$ & $0.45^{a} \pm 0.07$ & $1.26^{g} \pm 0.05$ & $1.59^{h} \pm 0.06$ & $2.97^{i} \pm 0.06$ & $1.03^{d} \pm 0.01$ & $1.10^{\mathrm{e}} \pm 0.01$ & $1.15^{e, f} \pm 0.02$ & $0.85^{b} \pm 0.06$ & $0.98^{c} \pm 0.01$ & $1.10^{e} \pm 0.08$ \\
\hline $\begin{array}{c}\text { TBARS, } \\
\mathrm{mg} \text { MDA/kg }\end{array}$ & $0.10^{a} \pm 0.02$ & $0.33^{c} \pm 0.07$ & $0.56^{d} \pm 0.08$ & $0.73^{e} \pm 0.08$ & $0.17^{a, b} \pm 0.03$ & $0.25^{\mathrm{b}, \mathrm{c}} \pm 0.05$ & $0.35^{\mathrm{c}} \pm 0.04$ & $0.12^{a} \pm 0.04$ & $0.20^{\mathrm{b}} \pm 0.04$ & $0.30^{c} \pm 0.06$ \\
\hline $\begin{array}{c}\text { a-Amino } \\
\text { nitrogen, mg/100 } \\
\mathrm{g}\end{array}$ & $15.98^{a} \pm 0.22$ & $18.24^{c} \pm 0.27$ & $19.31^{d} \pm 0.44$ & $21.36^{\mathrm{e}} \pm 0.53$ & $16.77^{b} \pm 0.34$ & $17.17^{b} \pm 0.59$ & $18.02^{c} \pm 0.13$ & $16.81^{b} \pm 0.52$ & $17.16^{b} \pm 0.31$ & $17.97^{c} \pm 0.32$ \\
\hline $\begin{array}{c}\text { TVB-N, } \\
\mathrm{mg} \mathrm{N}_{2} / 100 \mathrm{~g}\end{array}$ & $13.96^{a} \pm 1.25$ & $36.62^{c} \pm 0.87$ & $\begin{array}{c}47.53^{\mathrm{d}, \mathrm{e}} \pm \\
1.22\end{array}$ & $59.92^{f} \pm 1.30$ & $24.43^{b} \pm 0.91$ & $35.16^{c} \pm 1.12$ & $45.54^{d} \pm 1.14$ & $24.21^{b} \pm 0.98$ & $34.59^{c} \pm 0.95$ & $45.38^{d} \pm 1.11$ \\
\hline
\end{tabular}

Table 1: Changes of physicochemical quality parameters in muscle tissue of super chilled golden rainbow trout (Oncorcynchus mykiss) during $21 \mathrm{~d}$ of storage.

[40]. Cathepsins B and B+L were not deactivated in portions of fillets of farmed Atlantic salmon (Salmo salar) super chilled at $-1.4^{\circ} \mathrm{C}$ and $-3.6^{\circ} \mathrm{C}[40]$.

\section{Free fatty acids}

Degree of lipid hydrolysis in this study was evaluated by determining the amount of FFA. Variations in the mean values of FFA in three samples displayed a substantial increase to 21 days refrigerated storage (Table 1). Differences in averages between FFA of chilled and super chilled samples were statistically significant $\left(p^{*}<0.05\right)$ even after 7 days of refrigeration. On 21 day of storage of chilled fish FFA increased 9.5 times $\left(\mathrm{p}^{*}<0.05\right)$ (from $0.02 \%$ to $0.19 \%$ oleic acid). Applying both methods for super-chilling of golden rainbow trout contribute to very slight increase $(0.03 \%$ oleic acid) at the level of FFA, and they do not differ statistically significant $\left(\mathrm{p}^{*}>0.05\right)$.

Two factors responsible for very slow liberation of free fatty acids in two supper chilled samples can be highlighted. One of them is very small equivalent diameters of the intracellular ice crystals obtained upon super chilling (between $17 \mu \mathrm{m} \pm 2 \mu \mathrm{m}$ and $29 \mu \mathrm{m} \pm 1 \mu \mathrm{m}$ ) formed in the red and white muscles [41]. The second one is the gutting and evisceration of trout, followed by washing. That technological operations might have considerably reduced the microbial contamination in the belly area and hence the hydrolysis of lipid by microbial enzyme got reduced [42]. Triglycerides in the depot fish oils cleaved by triglyceride lipase originating from the digestive tract or excreted by certain microorganisms [42].

\section{Peroxide value}

Due to the unsaturated nature of the golden rainbow trout lipids they are very unstable to oxidation. By the POV was found the amount of primary products of lipid oxidation in fish muscle, namely formed in the induction period-so called lipid hydroperoxides (Table 1). POV of fresh fish was $0.45 \mu \mathrm{eqO} / \mathrm{kg}$. In the control samples-chilled golden rainbow trout a steady increase in POV within 21 days of storage at $0^{\circ} \mathrm{C}$ to $4^{\circ} \mathrm{C}$ was found associated with 6.6 times increase and maximal value of the POV of $2.97 \mu \mathrm{eqO} / \mathrm{kg}$. In contrast, POV in both super chilled fish samples were significantly $\left(\mathrm{p}^{*}<0.05\right)$ lower-an increase of about 2.5 times and reached maximum levels of hydroperoxides after 21 days at $-2^{\circ} \mathrm{C}$ to $-3^{\circ} \mathrm{C}$ of $1.10 \mu \mathrm{eqO} \mathrm{O}_{2} / \mathrm{kg}$. Thus, the results obtained testify to the fact that under the experiment conditions undergoing processes of lipid oxidation initiation, but similar to the free fatty acids levels POV are relatively low in two super chilled samples of golden rainbow trout. When conducted statistical comparison of POV of two experimental samples were set with the result significantly different $(p>0.05)$ in either one day of their storage.

Our results are similar of the data reported by Viji [42] for stored in ice sutchi catfish (Pangasianodon hypophthalmus) could be attributed to the fact that in the gills area are localized many very active oxidative enzymes, which at the supper-quick temperature decreasing, such as supper chilling, formed small the size ice crystals [43], and thus hindering the dissolution of atmospheric oxygen in the tissue fluid. Therefore, significantly reduces the possibility of attack of the substrateunsaturated fatty acids from fish oil of the active oxygen species mainly responsible for the initiation of lipid oxidation in fish [44].

\section{Tiobarbituric acid reactive substances}

TBARS is a value which shows the degree of accumulation of one of the secondary products of lipid oxidation, namely malondialdehyde (MDA). Changes in TBARS value of samples for storage period are also presented in Table 1. Fresh golden rainbow trout showed TBARS than $0.10 \mathrm{mg} \mathrm{MDA} / \mathrm{kg}$ was determined. There was a significant difference $\left(p^{*}<0.05\right)$ between TBARS of chilled and supper chilled samples. In chilled fish (control samples), TBARS increased significantly and reached $0.73 \mathrm{mg} \mathrm{MDA} / \mathrm{kg}$ of 21 days. TBARS of the two experimental samples golden rainbow trout they differ significantly $\left(p^{*}>0.05\right)$. It was found to gradually increase in TBARS values never crossed $0.35 \mathrm{mg}$ $\mathrm{MDA} / \mathrm{kg}$ at any time during the storage period. The limit of acceptability for TBARS is $2 \mathrm{mg} \mathrm{MDA} / \mathrm{kg}$, and then the fish usually develop a very unpleasant rancid smell and taste. In this study, TBARS was within acceptable throughout shelf life and two experimental samples during the storage period. Our findings are similar of the results of Liu [39] which were established an increasing trend of thiobarbituric acidreactive substances exhibited similar to that obtained with the microbial growth in common carp (Cyprinus carpio) surimi super chilled at $-3^{\circ} \mathrm{C}$. TBARS results are in good agreement with data as free fatty acids and cleaning, as well as those of microbiological and sensory analysis.

\section{Free $\alpha$-amino nitrogen}

Free alpha-amino nitrogen is the main representative of the group of non-protein nitrogen-containing compounds in fish. In this study, it was found that the FAN content in fresh golden rainbow trout is relatively low- $15.98 \mathrm{mg} / 100 \mathrm{~g}$ (Table 1). During the storage, the control 
Citation: Kitanovski VD, Vlahova-Vangelova DB, Dragoev SG, Nikolov HN, Balev DK (2017) Extension the Shelf-Life of Fresh Golden Rainbow Trout via Ultra-Fast Air or Cryogenic Carbon Dioxide Super Chilling. J Aquac Res Development 8: 481. doi: 10.4172/2155-9546.1000481

Page 6 of 9

\begin{tabular}{|c|c|c|c|}
\hline \multirow[b]{2}{*}{ Biogenic amines } & \multicolumn{3}{|c|}{ Concentration, $\mathrm{mg} / \mathrm{kg}$} \\
\hline & $\begin{array}{c}\text { Control sample-Golden rainbow trout } \\
\text { (Oncorhynchus mykiss) chilled by flake } \\
\text { ice and stored at } 0^{\circ} \mathrm{C} \text { to } 4^{\circ} \mathrm{C}\end{array}$ & $\begin{array}{l}\text { Cryogenic super chilled golden rainbow trout } \\
(\text { Oncorhynchus mykiss) by dry carbon dioxide at } \\
-78^{\circ} \mathrm{C} \text { with flow } 0.5 \mathrm{~m} / \mathrm{s} \text {, and stored at }-2^{\circ} \mathrm{C} \text { to }-3^{\circ} \mathrm{C}\end{array}$ & $\begin{array}{l}\text { Ultra-fast super chilled golden rainbow trout } \\
\text { (Oncorhynchus mykiss) by cold air at }-20^{\circ} \mathrm{C} \\
\text { with flow } 3.0 \mathrm{~m} / \mathrm{s} \text {, and stored at }-2^{\circ} \mathrm{C} \text { to }-3^{\circ} \mathrm{C}\end{array}$ \\
\hline Putrescine & $22.78^{b} \pm 0.29$ & traces $^{a}$ & traces $^{a}$ \\
\hline Cadaverine & $50.64^{c} \pm 0.33$ & $10.40^{b} \pm 0.02$ & traces $^{a}$ \\
\hline Histamine & $12.35^{\mathrm{b}} \pm 0.27$ & traces $^{a}$ & traces $^{a}$ \\
\hline Tyramine & $18.17^{c} \pm 0.26$ & traces $^{b}$ & not identified $^{\text {a }}$ \\
\hline
\end{tabular}

Table 2: Accumulation of biogenic amines in muscle tissue of chilled and super chilled golden rainbow trout (Oncorcynchus mykiss) after $21 \mathrm{~d}$ of storage.

samples (chilled golden rainbow trout) has significantly $\left(\mathrm{p}^{*}<0.05\right)$ in an accelerated increase of the FAN content, compared with the super chilled samples, was observed (Table 1). In chilled golden rainbow trout storied $21 \mathrm{~d}$ at $0^{\circ} \mathrm{C}$ to $4^{\circ} \mathrm{C}$ FAN increased by $33.7 \%$. In two super chilled samples the FAN increases is only $12.5 \%$ to $12.8 \%$ was found (Table 1). FAN values recorded during the storage of cryogenic super chilled golden rainbow trout and ultra-fast super chilled fish don't differ significantly $\left(\mathrm{p}^{*}>0.05\right)$ (Table 1$)$.

Viji [42] argue that in gutted fish FAN content rising is relatively slow. According to the same researchers FAN content increases surgery to remove part of the release of free amino acids from muscle proteins due to the operation of both the endogenous proteolytic enzymes, and such of microbiological origin. At a later stage by storing these free amino acids undergo further degradation and release volatile bases and other low molecular weight nitrogen containing compounds. In the conditions of this study the FAN levels which were determined (between $16.77 \mathrm{mg} / 100 \mathrm{~g}$ and $18.02 \mathrm{mg} / 100 \mathrm{~g}$ ) in two supper chilled golden rainbow trout samples are on the upper limit for fishes (17 $\mathrm{mg} / 100 \mathrm{~g}$ to $81 \mathrm{mg} / 100 \mathrm{~g}$ ) discussed in the by Viji [42].

During super chilled fish storage at $-1.4^{\circ} \mathrm{C}$ and $-3.6^{\circ} \mathrm{C}$, the myofibrillar and collagenous proteins were intensively hydrolysed by proteases. Duun and Rustad [40] also supported the similar explanation finding that cathepsins $\mathrm{B}$ and $\mathrm{B}+\mathrm{L}$ were not deactivated at the shown above storage temperatures.

\section{Total volatile base nitrogen}

Chemical deterioration in the fish during cold storage is typically assessed by changes in the TVB-N content, which consists essentially of ammonia and primary, secondary and tertiary amines. Variations in the mean TVB-N values of the three fish samples are presented in Table 1. TVB-N value of fresh fish was $13.96 \mathrm{mg} \mathrm{N} / 100 \mathrm{~g}$. In the control sample (chilled golden rainbow trout), the TVB-N increases much more accelerated in the process of storage compared to the twoexperimental super chilled samples, was determined. Even after the seventh day of storage the TVB-N value in a chilled control sample was with $33.5 \%$ higher than those established in the two-super chilled experimental samples. This trend continued after 14 days of storage, when the chilled golden rainbow trout has with $26.6 \%$ higher TVB-N content and at the end of the experiment, on 21 day of storage, when TVB-N content of this sample was with $24.1 \%$ higher comparing to levels determined in two experimental samples. The TVB-N values in the two experimental samples, cryogenic super chilled by dry carbon dioxide golden rainbow trout, and ultra-fast super chilled golden rainbow trout, don't differ significantly $\left(\mathrm{p}^{*}>0.05\right)$ throughout the 21 day storage period.

Different levels of eligibility of TVB-N value were reported, depending on the species, specific procedures and conditions for treatment. Contrary to the results reported by Conte et al. [45] in our experiment was determined the significant increases $\left(\mathrm{p}^{*}<0.05\right)$ in TVB-N values during the 21 days of storage of chilled samples.

Shen [34] believe that TVB-N may be inadequate for evaluating freshness changes of rainbow trout (Oncorhynchus mykiss) fillets compared with other indicators. Similar to our results, Shen [34] found that after 11 days of storage at $-3^{\circ} \mathrm{C}$ TVB-N and other freshness indicators (TAC, $\mathrm{K}$ value, sensory scores) were relatively low. Mi [37], and Liu [39] reach to similar conclusions studying on the total volatile basic nitrogen (TVB-N), and trimethylamine nitrogen (TMA-N) in whole ungutted and filleted grass carp (Ctenopharyngodon idellus) during super chilled storage at $-2^{\circ} \mathrm{C}$ to $-3^{\circ} \mathrm{C}$. Those authors concluded that TVB-N and TMA-N can be controlled under the acceptable values within 21 days. Similar findings were reported by Olafsdottir [46] for super chilled cod (Gadus morhua) fillets storied $15 \mathrm{~d}$ at $-1.5^{\circ} \mathrm{C}$; Liu [39] for common carp (Cyprinus carpio) surimi processed with cryoprotectants (a mixture of sucrose and sorbitol) super chilled at $-3^{\circ} \mathrm{C}$; and Zhu [47] for catfish (Clarias gariepinus) fillets stored at $-0.7^{\circ} \mathrm{C}$ under different packaging atmospheres: air (AP), vacuum (VP), and $60 \% \mathrm{CO}_{2} / 40 \% \mathrm{~N}_{2}$ (MAP) (Table 1 ).

\section{Biogenic amines}

A confirmation that the processes of microbial deterioration flow very slow in two types of super chilled golden rainbow trout is the absence of biogenic amines in two experimental samples after their 21 day of storage (Table 2). The presence of $10.40 \mathrm{mg} / \mathrm{kg}$ cadaverine $\left(\mathrm{p}^{*}<0.05\right)$ in cryogenic dry carbon dioxide super chilled golden rainbow trout only, was determined. It should be noted that this is a comparatively low concentration on the edge of the sensitivity of HPLC method used for determination of biogenic amines. As evidenced by the data presented (Table 2) in the control samples chilled fish after 21 days cold storage were significantly $\left(\mathrm{p}^{*}<0.05\right)$ higher concentrations of biogenic amines. The major finding of the study was that the concentrations of the biogenic amine (putrescine, cadaverine, tyramine and histamine), increased significantly $\left(\mathrm{p}^{*}<0.05\right)$ together with a significant increase in $\mathrm{pH}=7.99$ over the 21 -day storage period in continually higher levels of free $\alpha$-amino nitrogen, and TVB-N observed after the $21^{\text {st }}$ day of storage in the chilled samples, only.

Our results are similar of those reported by Rezaei [48] which was found that the levels of putrescine, cadaverine and histamine, and bacterial loads, increased $(\mathrm{P}<0.05)$ during 18 -days ice storage of whole farmed rainbow trout (Oncorhynchus mykiss). According to Rezaei [48] the content of biogenic amine is related with changes of Pseudomonas spp., psychrotrophic and mesophilic bacteria counts. Zhu [47] regarded that super chilling of catfish (Clarias gariepinus) at $-0.7^{\circ} \mathrm{C}$ inhibits microbial growth, accompanied by a nucleotides degradation, conversion of protein to volatile-based nitrogen and biogenic amines, and production of trimethylamine nitrogen, as well as loss of sensory quality. 
Citation: Kitanovski VD, Vlahova-Vangelova DB, Dragoev SG, Nikolov HN, Balev DK (2017) Extension the Shelf-Life of Fresh Golden Rainbow Trout via Ultra-Fast Air or Cryogenic Carbon Dioxide Super Chilling. J Aquac Res Development 8: 481. doi: 10.4172/2155-9546.1000481

Page 7 of 9

\begin{tabular}{|c|c|c|c|c|c|c|c|c|c|c|}
\hline \multirow[t]{3}{*}{ Examined parameter } & \multicolumn{4}{|c|}{$\begin{array}{c}\text { Control sample-Golden rainbow trout } \\
\text { (Oncorhynchus mykiss) chilled by flake ice and } \\
\text { stored at } 0^{\circ} \mathrm{C} \text { to } 4^{\circ} \mathrm{C}\end{array}$} & \multicolumn{3}{|c|}{$\begin{array}{l}\text { Cryogenic super chilled golden rainbow } \\
\text { trout (Oncorhynchus mykiss) by dry } \\
\text { carbon dioxide at }-78^{\circ} \mathrm{C} \text { with flow } 0.5 \mathrm{~m} / \mathrm{s} \text {, } \\
\text { and stored at }-2^{\circ} \mathrm{C} \text { to }-3^{\circ} \mathrm{C}\end{array}$} & \multicolumn{3}{|c|}{$\begin{array}{c}\text { Ultra-fast super chilled golden rainbow } \\
\text { trout (Oncorhynchus mykiss) by cold air } \\
\text { at }-20^{\circ} \mathrm{C} \text { with flow } 3.0 \mathrm{~m} / \mathrm{s} \text {, and stored at } \\
-2^{\circ} \mathrm{C} \text { to }-3^{\circ} \mathrm{C}\end{array}$} \\
\hline & \multicolumn{10}{|c|}{ Day of storage } \\
\hline & $0 \mathrm{~d}$ & $7 d$ & 14d & 21d & $7 d$ & 14d & 21d & $7 d$ & $14 d$ & 21d \\
\hline $\begin{array}{l}\text { Facultative anaerobic } \\
\text { mesophilic } \\
\text { microorganisms log cfu/ } \\
\mathrm{cm}^{2} \text { skin }\end{array}$ & $\begin{array}{l}2.85^{\mathrm{a}} \log \\
\mathrm{cfu} / \mathrm{cm}^{2}\end{array}$ & $\begin{array}{c}4.79^{\mathrm{d}} \log \mathrm{cfu} / \\
\mathrm{cm}^{2}\end{array}$ & $\begin{array}{c}5.63^{\mathrm{f}} \log \mathrm{cfu} / \\
\mathrm{cm}^{2}\end{array}$ & $\begin{array}{l}6.97^{i} \log \\
\mathrm{cfu} / \mathrm{cm}^{2}\end{array}$ & $\begin{array}{c}4.11^{\mathrm{b}} \log \mathrm{cfu} / \\
\mathrm{cm}^{2}\end{array}$ & $\begin{array}{c}4.82^{\mathrm{e}} \log \mathrm{cfu} / \\
\mathrm{cm}^{2}\end{array}$ & $\begin{array}{l}6.15^{\mathrm{h}} \mathrm{log} \\
\mathrm{cfu} / \mathrm{cm}^{2}\end{array}$ & $\begin{array}{l}4.26^{\mathrm{c}} \mathrm{log} \\
\mathrm{cfu} / \mathrm{cm}^{2}\end{array}$ & $\begin{array}{c}4.83^{\mathrm{e}} \log \mathrm{cfu} / \\
\mathrm{cm}^{2}\end{array}$ & $\begin{array}{c}5.85^{\mathrm{g}} \log \mathrm{cfu} / \\
\mathrm{cm}^{2}\end{array}$ \\
\hline $\begin{array}{c}\text { Facultative } \\
\text { anaerobic } \\
\text { mesophilic } \\
\text { microorganisms log } \\
\text { cfu/g muscle tissue }\end{array}$ & $\begin{array}{c}2.83^{\mathrm{a}} \log \\
\mathrm{cfu} / \mathrm{g}\end{array}$ & $4.67^{f} \log \mathrm{cfu} / \mathrm{g}$ & $5.57^{9} \log \mathrm{cfu} / \mathrm{g}$ & $\begin{array}{c}6.38^{\mathrm{j}} \log \\
\mathrm{cfu} / \mathrm{g}\end{array}$ & $4.0^{\mathrm{b}} \log \mathrm{cfu} / \mathrm{g}$ & $4.46^{\mathrm{d}} \log \mathrm{cfu} / \mathrm{g}$ & $\begin{array}{c}5.84^{\mathrm{h}} \log \\
\mathrm{cfu} / \mathrm{g}\end{array}$ & $\begin{array}{c}4.15^{\circ} \log \\
\mathrm{cfu} / \mathrm{g}\end{array}$ & $4.49^{\mathrm{e}} \log \mathrm{cfu} / \mathrm{g}$ & $5.79^{\mathrm{h}} \log \mathrm{cfu} / \mathrm{g}$ \\
\hline $\begin{array}{l}\text { Psychrotrophic } \\
\text { microorganisms log cfu/ } \\
\mathrm{cm}^{2} \text { skin }\end{array}$ & $\begin{array}{l}2.69^{\mathrm{a}} \mathrm{log} \\
\mathrm{cfu} / \mathrm{cm}\end{array}$ & $4.28^{\mathrm{d}} \log \mathrm{cfu} / \mathrm{cm}^{2}$ & $\begin{array}{c}5.46^{9} \log \mathrm{cfu} / \\
\mathrm{cm}^{2}\end{array}$ & $\begin{array}{l}6.62^{i} \log \\
\mathrm{cfu} / \mathrm{cm}^{2}\end{array}$ & $\begin{array}{c}3.91^{\mathrm{b}} \log \mathrm{cfu} / \\
\mathrm{cm}^{2}\end{array}$ & $\begin{array}{l}4.79^{\mathrm{e}} \log \mathrm{cfu} / \\
\mathrm{cm}^{2}\end{array}$ & $\begin{array}{l}6.17^{\mathrm{h}} \mathrm{log} \\
\mathrm{cfu} / \mathrm{cm}^{2}\end{array}$ & $\begin{array}{l}4.08^{\mathrm{c}} \log \\
\mathrm{cfu} / \mathrm{cm}^{2}\end{array}$ & $\begin{array}{c}4.81^{\mathrm{f}} \log \mathrm{cfu} / \\
\mathrm{cm}^{2}\end{array}$ & $\begin{array}{c}6.21^{\mathrm{h}} \log \mathrm{cfu} / \\
\mathrm{cm}^{2}\end{array}$ \\
\hline $\begin{array}{l}\text { Psychrotrophic } \\
\text { microorganisms log } \\
\text { cfu/g muscle tissue }\end{array}$ & $\begin{array}{c}2.66^{\mathrm{a}} \log \\
\mathrm{cfu} / \mathrm{g}\end{array}$ & $4.04^{\mathrm{d}} \log \mathrm{cfu} / \mathrm{g}$ & $5.2^{\mathrm{g}} \log \mathrm{cfu} / \mathrm{g}$ & $\begin{array}{c}6.56^{\mathrm{j} l o g} \\
\text { cfu/g }\end{array}$ & $3.78^{b} \log \mathrm{cfu} / \mathrm{g}$ & $4.32^{\mathrm{e}} \log \mathrm{cfu} / \mathrm{g}$ & $\begin{array}{l}5.32^{i} \log \\
\text { cfu/g }\end{array}$ & $\begin{array}{l}3.89^{\circ} \log \\
\mathrm{cfu} / \mathrm{g}\end{array}$ & $4.46^{\mathrm{f}} \log \mathrm{cfu} / \mathrm{g}$ & $5.79^{\mathrm{h}} \log \mathrm{cfu} / \mathrm{g}$ \\
\hline
\end{tabular}

Data were expressed as Mean $\pm S D(n=7)$. ${ }^{a, b, c, d, e, f, g, h, i, j}$ - different letters indicated that values of the means in the rows are significantly different $\left({ }^{*} \mathrm{p}<0.05\right)$.

Table 3: A total plate count of facultative anaerobic mesophilic microorganisms and psychrotrophic microorganisms in muscle tissue and on skin surface of chilled and super chilled golden rainbow trout (Oncorcynchus mykiss) stored $21 \mathrm{~d}$.

Concentration of histamine, putrescine, and tyramine weren't suitable biogenic amines as freshness indicators for supper chilled golden rainbow trout. Only the cadaverine content in cryogenically super chilled samples by dry $\mathrm{CO}_{2}$ could be a comparatively good quality marker, but only on the end of the storage (after $21^{\text {st }}$ day) at $-2^{\circ} \mathrm{C}$ to $-3^{\circ} \mathrm{C}$. The two studied methods for super chilling of golden rainbow trout practically eliminate the biogenic amines formation during all period of storage (to $21^{\text {st }} \mathrm{d}$ ) (Table 2).

\section{Total plate count of facultative anaerobic and psychrotrophic microorganisms on the skin surface and in muscle tissue}

Super chilling of fish samples caused a reduction in the bacterial grout and thereafter, the counts gradually increased. The results about presence of biogenic amines (Table 2) mentioned above show that the two tested types for supper chilling of golden rainbow trout are suitable for inhibiting the development of putrefactive micro-flora and can prevent the rapid increase of the TPC of FAMM and PM on both the surface of the fish, and in fish muscles (Table 3) in comparison with flake ice fish chilling. During the 21 days' period of refrigeration storage, TPC of FAMM and TPC of PM increase more expressed at control samples (Table 3). For comparison, according to Shen [34], the total aerobic count (TAC) limited the acceptability of rainbow trout (Oncorhynchus mykiss) fillets to 5 days at $3^{\circ} \mathrm{C}$ and 11 days at $-3^{\circ} \mathrm{C}$, and according to Viji [42] for 20 days and 18 days, respectively at $0^{\circ} \mathrm{C}$ to $2^{\circ} \mathrm{C}$ during ice storage of whole ungutted catfish and gutted catfish. The total plate count of psychrotrophic microorganisms on both the surface of the samples, and in muscle tissue is lower in comparison with this one of facultative anaerobic mesophilic microorganisms (Table 3). Similarly to our results the super chilled storage at $-2.2^{\circ} \mathrm{C}$ of fillet portions of farmed Atlantic cod (Gadus morhua) showed increased shelf life with respect to reduced growth of sulphide producing bacteria compared to ice chilled [36]; super chilled $\left(-1.5^{\circ} \mathrm{C}\right)$ storage of aerobically packed cod (Gadus morhua) fillets was characterized by the growth of specific spoilage organisms and the production of microbial metabolites measured by an electronic nose [49]. When supper chilling combines with natural additives, and modified atmosphere packaging (MAP) the shelf-life prolongs to 22 days of Fernández [50] to 24 days to Sivertsvik [51] for Atlantic salmon (Salmo salar) fillets, and to 13 days only for farmed spotted wolf-fish (Anarhichas minor) [52] (Table 3).

\section{Conclusions}

Super chilling extended the microbial shelf life of air packed gutted golden rainbow trout by two weeks compared to traditional ice chilling. The total plate count of facultative anaerobic mesophilic and psychrophilic microorganisms in the super chilled golden rainbow trout were several times lower compared to the ice chilled one. In the present study, two types super chilled as well as ice chilled golden rainbow trout never crossed the prescribed acceptance limit of no one of studied biochemical quality parameters. $\mathrm{pH}$ of both ultra-fast air flow or dry carbon dioxide super chilled golden rainbow trout has shown no significant changes during storage. Ultra-fast air flow and dry carbon dioxide super chilling significantly reduced volatile base generation and free amino nitrogen content, and significantly slow down the development of lipolytic and oxidative processes of the lipid fraction of gutted golden rainbow trout. Although sensory data show a continued acceptability to fourteen days for super chilled (21 days) than in cooled flake ice (7 days) golden rainbow trout. The microbiological shelf life shall be extended by 16-18 days and 10-12 days super chilling, respectively against flake ice chilling. This study revealed that the ultrafast air flow super chilling retains better sensory qualities of golden rainbow trout while super chilling with dry carbon dioxide makes the appearance of the fish are unacceptable to consumers, thereby limiting the shelf life. Therefore, to maintain quality of eviscerated golden rainbow trout during the super chilling process should be optimized in terms of speed and degree of super chilling, as to minimize frost denaturation of proteins. At the same time, the temperature must be low enough to provide an increase in the shelf life and suppression of putrefactive microorganisms.

\section{Acknowledgments}

The authors would like to acknowledge the University of Food Technology, Plovdiv, Ribena Ltd., Zlatna Panegs, and PhD student Atanaska Vassileva for thei support and help.

\section{References}

1. Kaale LD, Eikevik TM (2013a) A histological study of the microstructure sizes of the red and white muscles of Atlantic salmon (Salmo salar) fillets during super chilling process and storage. J Food Eng 114: 242-248. 
Citation: Kitanovski VD, Vlahova-Vangelova DB, Dragoev SG, Nikolov HN, Balev DK (2017) Extension the Shelf-Life of Fresh Golden Rainbow Trout via Ultra-Fast Air or Cryogenic Carbon Dioxide Super Chilling. J Aquac Res Development 8: 481. doi: 10.4172/2155-9546.1000481

2. Kaale LD, Eikevik TM (2013b) A study of the ice crystal sizes of red muscle of pre-rigor Atlantic salmon (Salmo salar) fillets during super chilled storage. $J$ Food Eng 119: 544-551.

3. Ghanbari M, Jami M, Domig KJ, Kneifel W (2013) Seafood bio preservation by lactic acid bacteria: A review. LWT-Food Sci Technol Int 54: 315-324.

4. Dalgaard P, Madsen HL, Samieian N, Emborg J (2006) Biogenic amine formation and microbial spoilage in chilled garfish (Belone belone belone)effect of modified atmosphere packaging and previous frozen storage. J Appl Microbiol 101: 80-95.

5. Magnussen OM, Haugland A, Torstveit HAK, Johansen S, Nordtvedt TS (2008) Advances in super chilling of food-Process characteristics and product quality. Trends Food Sci Tech 19: 418-424.

6. Thorgaard GH, Spruell P, Wheeler PA, Scheerer PD, Peek AS, et al. (1995) Incidence of albinos as a monitor for induced triploidy in rainbow trout. Aquaculture 137: 121-130.

7. Dobosz S, Kohlmann K, Goryczko K, Kuzminski H (2000) Growth and vitality in yellow forms of rainbow trout. J App Ichthyol 16: 117-120.

8. Medina I, Gallardo JM, Aubourg SP (2009) Quality preservation in chilled and frozen fish products by employment of slurry ice and natural antioxidants. Quality preservation in chilled and frozen fish products by employment of slurry ice and natural antioxidants. Int J Food Sci Tech 44 : 1467-1479.

9. Himelbloom BH, Crapo C, Brown EK, Babbitt J, Reppond K (1994) Pink salmon (Oncorhynchus gorbuscha) quality during ice and chilled seawater storage. J Food Quality 17: 197-210.

10. Huidobro A, Mendes R, Nunes ML (2001) Slaughtering of gilthead sea bream (Sparus aurata) in liquid ice: Influence on fish quality. Eur Food Res Technol 213: $267-272$.

11. Lucas T, Raoult-Wack AL (1998) Immersion chilling and freezing in aqueous refrigerating media: Review and future trends. Int J Refrig 21: 419-429.

12. Fukuma $Y$, Yamane A, Itoh $T$, Tsukamasa $Y$, Ando $M$ (2012) Application of super cooling to long-term storage of fish meat. Fisheries Sci 78: 451-461.

13. Fik M, Surówka K, Leszczynska-Fik A (1988) Application of super chilling to prolong the keeping time of rainbow trout. Food Nahrung 32: 291-300.

14. Kaale LD, Eikevik TM, Rustad T, Kolsaker K (2011) Super chilling of food: A review. J Food Eng 107: 141-146.

15. Wu C, Yuan C, Ye X, Hu Y, Chen S, et al. (2014) A critical review on super chilling preservation technology in aquatic product. J Integrative Agricult 13: 2788-2806.

16. George RM (1993) Freezing processes used in the food industry. Trends Food Sci Tech 4: 134-138.

17. Liu SL, Lu F, Xu XB, Ding YT (2010) Super-chilling maintains freshness of modified atmosphere-packaged Lateolabrax japonicus. Int J Food Sci Tech 45: $1932-1938$.

18. Huan Z, He S, Ma Y (2003) Numerical simulation and analysis for quick-frozen food processing. J Food Eng 60: 267-273.

19. Sasi M, Jeyasekaran G, Shanmugam SA, Jeya Shakila R (2003) Evaluation of the quality of seer fish (Scomberomorus commersonii) stored in dry ice (solid carbon dioxide). J Aquat Food Prod T 12: 61-72.

20. Awonorin SO (1989) A model for heat transfer in cryogenic food freezing. Int $J$ Food Sci Technol 24: 243-259.

21. Archer $M(2010)$ Sensory assessment scoresheets for fish and shellfish-Torry \& QIM, Seafish, Edinburgh

22. Fan W, Sun J, Chen Y, Qu J, Zhang Y, et al. (2009) Effects of chitosan coating on quality and shelf life of silver carp during frozen storage. Food Chem 115: $66-70$

23. Korkeala H, Mäki-Petäys O, Alanko T, Sorvettula O (1986) Determination of $\mathrm{pH}$ in meat. Meat Sci 18: 121-132.

24. Gheisari HR (2011) Correlation between acid, TBA, peroxide and iodine values, catalase and glutathione peroxidase activities of chicken, cattle and camel meat during refrigerated storage. Vet World 4: 153-157.

25. AOAC (2012) Official Method 940.28. Methods of Analysis of AOAC International. (19thedn), AOAC International, Rockville, MD.
26. Hornero-Méndez D Gálvez AP, Mínguez MMI (2001)A rapid spectrophotometric method for the determination of peroxide value in food lipids with high carotenoid content. J Am Oil Chem Soc 78: 1151-1155.

27. Botsoglou NA, Fletouris DJ, Papageorgiou GE, Vassilopoulos VN, Mantis AJ, et al. (1994) A rapid, sensitive, and specific thiobarbituric acid method for measuring lipid peroxidation in animal tissues, food, and feed stuff samples. $J$ Agric Food Chem 42: 1931-1937.

28. Jebelli JA, Ghazvinian K, Mahdavi A, Javaheri VA, Staji H, et al. (2012) The effect of dietary Zataria multiflora Boiss essential oil supplementation on microbial growth and lipid peroxidation of broiler breast fillets during refrigerated storage. J Food Process Pres 37: 881-888.

29. Abernathy DG, Spedding G, Starcher B (2009) Analysis of protein and total usable nitrogen in beer and wine using a microwell ninhydrin assay. J Inst Brew 115: $122-127$.

30. Goulas AE, Kontominas MG (2005) Effect of salting and smoking method on the keeping quality of chub mackerel (Scomber japonicus): biochemical and sensory attributes. Food Chem 93: 511-520.

31. Sharma S, Aneja MK, Mayer J, Munch JC, Schloter M (2005) Characterization of bacterial community structure in rhizosphere soil of grain legumes. Microb Ecol 49: 407-415.

32. ISO 4833:2003. Microbiology of food and animal feeding stuffs. Horizontal method for the enumeration of microorganisms-Colony-count technique at $30^{\circ} \mathrm{C}$

33. ISO 17410:2002. Microbiology of food and animal feeding stuffs-Horizontal method for the enumeration of psychrotrophic microorganisms.

34. Shen S, Jiang Y, Liu X, Luo Y, Gao L (2015) Quality assessment of rainbow trout (Oncorhynchus mykiss) fillets during super chilling and chilled storage. J Food Sci Tech Mys 52: 5204-5211.

35. Bao HND, Arason S, Thórarinsdóttir KA (2007) Effects of dry ice and supe chilling on quality and shelf life of Arctic charr (Salvelinus alpinus) fillets. Int $J$ Food Eng 3: 1-27.

36. Duun AS, Rustad T (2007) Quality changes during super chilled storage of cod (Gadus morhua) fillets. Food Chem 105: 1067-1075.

37. Mi H, Qian C, Zhao Y, Liu C, Mao L (2013) Comparison of super chilling and freezing on microstructure, muscle quality and protein denaturation of grass carp (Ctenopharyngodon idellus). J Food Process Pres 37: 546-554

38. Liu D, Liang L, Xia W, Regenstein JM, Zhou P (2013) Biochemical and physical changes of grass carp (Ctenopharyngodon idella) fillets stored at $-3^{\circ} \mathrm{C}$ and $0^{\circ} \mathrm{C}$ Food Chem 140: 105-114.

39. Liu Q, Kong B, Han J, Chen Q, He X (2014) Effects of super chilling and cryoprotectants on the quality of common carp (Cyprinus carpio) surimi Microbial growth, oxidation, and physiochemical properties. LWT - Food Sci Tech 57: 165-171.

40. Duun AS, Rustad T (2008) Quality of super chilled vacuum packed Atlantic salmon (Salmo salar) fillets stored at $1.4^{\circ} \mathrm{C}$ and $3.6^{\circ} \mathrm{C}$. Food Chem 106 122-133.

41. Kaale LD, Eikevik TM, Rustad T, Nordtvedt TS, Bardal T (2013b) Ice crysta development in pre-rigor Atlantic salmon fillets during super chilling process and following storage. Food Cont 31: 491-498

42. Viji P, Tanuja S, Ninan G, Lalitha KV, Zynudheen AA, et al. (2015) Biochemical, textural, microbiological and sensory attributes of gutted and ungutted sutch catfish (Pangasianodon hypophthalmus) stored in ice. J Food Sci Tech 52: 3312-3321.

43. Kaale LD, Eikevik TM, Bardal T, Kjorsvik E, Nordtvedt TS (2013a) The effect of cooling rates on the ice crystal growth in air-packed salmon fillets during super chilling and super chilled storage. Int J Refrig 36: 110-119.

44. Dragoev SG, Balev DK, Ivanov GY, Nikolova-Damyanova BM, Grozdeva TG, et al. (2014) Effect of superficial treatment with new natural antioxidant on salmon (Salmo salar) lipid oxidation. Acta Aliment Hung 43: 1-8.

45. http://dx.doi.org/10.5455/vetworld.2011.153-157.

46. Olafsdottir G, Lauzon HL, Martinsdóttir E, Oehlenschláuger J, Kristbergsson K (2006) Evaluation of shelf life of super chilled cod (Gadus morhua) fillets and the influence of temperature fluctuations during storage on microbial and chemical quality. J Food Sci 71: S97-S109. 
Citation: Kitanovski VD, Vlahova-Vangelova DB, Dragoev SG, Nikolov HN, Balev DK (2017) Extension the Shelf-Life of Fresh Golden Rainbow Trout via Ultra-Fast Air or Cryogenic Carbon Dioxide Super Chilling. J Aquac Res Development 8: 481. doi: 10.4172/2155-9546.1000481

47. Zhu Y, Ma L, Yang $H$, Xiao $Y$, Xiong YL (2016) Super-chilling $\left(-0.7^{\circ} \mathrm{C}\right)$ with high- $\mathrm{CO}_{2}$ packaging inhibits biochemical changes of microbial origin in catfish (Clarias gariepinus) muscle during storage. Food Chem 206: 182-190.

48. Rezaei M, Montazeri N, Langrudi HE, Mokhayer B, Parviz M, et al. (2007) The biogenic amines and bacterial changes of farmed rainbow trout (Oncorhynchus mykiss). Food Chem 103: 150-154.

49. Rodrigues BL, Alvares TS, da Costa MP, Lopes Sampaio GS, Lázaro de la Torre CA, et al. (2013) Concentration of biogenic amines in rainbow trout (Oncorhynchus mykiss) preserved in Ice and its relationship with physicochemical parameters of quality. J Aquac Res Develop 4: 1-4.
50. Fernández K, Aspé E, Roeckel M (2009) Shelf-life extension on fillets of Atlantic salmon (Salmo salar) using natural additives, super chilling and modified atmosphere packaging. Food Cont 20: 1036-1042.

51. Sivertsvik M, Rosnes JT, Kleiberg GH (2003) Effect of modified atmosphere packaging and super chilled storage on the microbial and sensory quality of Atlantic salmon (Salmo salar) fillets. J Food Sci 68: 1467-1472.

52. Rosnes JT, Kleiberg GH, Sivertsvik M, Lunestad BT, Lorentzen G (2006) Effect of modified atmosphere packaging and super chilled storage on the shelf-life of farmed ready-to-cook spotted wolf-fish (Anarhichas minor). Packag Technol Sci 19: 325-333. 